\title{
Seasonal diet of rabbits and their browsing effect on juniper in Bugac Juniper Forest (Hungary)
}

\author{
Katalin MÁTRAI, Vilmos ALTBÄCKER and István HAHN
}

\begin{abstract}
Mátrai K., Altbäcker V. and Hahn I. 1998. Seasonal diet of rabbits and their browsing effect on juniper in Bugac Juniper Forest (Hungary). Acta Theriologica 43: 107-112.

Seasonal foods of European rabbits Oryctolagus cuniculus (Linnaeus, 1758) were studied by microhistological analysis of pellets in a protected area Bugac Juniper Forest, Hungary. Field experiments were also conducted to examine the role of rabbit foraging on common juniper Juniperus communis. The proportion of grasses, forbs and browses changed significantly throughout the seasons $(p<0.0001)$. Spring diet was dominated by grasses (89\%), summer diet by grasses $(30 \%)$ and forbs $(42 \%)$, whereas in autumn grasses $(60 \%)$ and browse (24\%) were the main diet components. Juniper appeared only in winter diet (19\%) together with other browse $(60 \%)$. The high proportion of aromatic thyme Thymus glabrescens in summer diet (30\%) and juniper in winter diet indicates that monoterpenoids of these plants did not keep rabbits from consumption even when other food sources were available. Planted juniper seedlings disappeared within weeks due to the browsing by rabbits.
\end{abstract}

Gödölld̆ University of Agricultural Sciences, Department of Widlife Biology and Management, Páter K. u. 1, 2103 Gödöllø, Hungary, Tel: 28 310538; Fax: 28320189 (KM); Eötvös Lóránd University, Department of Ethology, Jávorka S. u. 1, 2131 Göd, Hungary (VA); Eötvös Lóránd University, Department of Plant Systematics and Ecology, Ludovika tér 2, 1083 Budapest, Hungary (IH)

Key words: Oryctolagus cuniculus, diet, juniper browsing, Hungary

\section{Introduction}

The protected area of Bugac Juniper Forest (BJF) has unique vegetation (Kertész et al. 1993). Recent observations suggest that the existence and natural regeneration of juniper are severely limited. Preliminary observations of herbivory by rabbits indicate they do browse on juniper shoots, and juniper patches are preferred sites for burrowing and hiding (Altbäcker et al. 1991). Laboratory experiments also suggested that young rabbits reared in the area preferred juniper at weaning (Altbäcker et al. 1995). However, direct information relating to either rabbit seasonal diet of this special area or juniper browsing, has not been reported.

The hypothesis that juniper is an important food source for rabbit was tested in this study by two ways. First, we analysed diet composition of rabbit living in BJF by microhistological analysis, and second, the access of rabbits to juniper was 
manipulated in experimental plots to quantify the effects of browsing by rabbits on the survival of juniper shoots in this forest.

\section{Material and methods}

The study was conducted in 1992 and 1993 on the BJF core area in Kiskunság National Park, central Hungary. The vegetation is dominated by grasslands (30\%), interspersed with patches of pure juniper (12\%), pure poplar (Populus alba and P. canescens, 18\%), juniper mixed with poplar (25\%), and pine (Pinus nigra and P. silvestris) forests (5\%) (Kertész et al. 1993). Dominant species within the shrub level are the shrub-sized juniper, poplar, willow Salix rosmarinifolia, privet Ligustrum vulgare and bramble (Rubus spp.). Fescue (Festuca spp.), reed grass Calamagrostis epigeios, brome (Bromus spp.), and sedge (Carex spp.) dominate the herbaceous level (Kalapos 1989).

For each season, one composite sample of fresh fecal pellets was collected (Anthony and Smith, 1974) along a $2 \mathrm{~km}$ permanent transect in October $(n=17$ in autumn), and December $(n=17$ in winter), 1992 and April ( $n=21$ in spring), June ( $n=14$ in summer), 1993. Sampling points were distributed at least at $100 \mathrm{~m}$ intervals to prevent possible overlaps from neighbouring individuals. Botanical composition of the composite samples was investigated by microhistological analysis of epidermis fragments (Baumgartner and Martin 1939, Dusi 1949, Mátrai and Kabai 1989) using a reference collection of plant species collected from the study area (Mátrai et al. 1986). Percent of

Table 1. Experimental designe of shoot individuals for controlling the effects of rabbits on juniper browsing in BJF, 1992. Numbers 1-24 represent individuals of juniper.

\begin{tabular}{|c|c|c|c|}
\hline \multicolumn{2}{|c|}{ First month } & \multicolumn{2}{|c|}{ Second month } \\
\hline Browsed & Fenced & Browsed & Fenced \\
\hline 1 & 4 & 1 & 4 \\
\hline 2 & 5 & 2 & 5 \\
\hline 3 & 6 & 3 & 6 \\
\hline 7 & 10 & 7 & 10 \\
\hline 8 & 11 & 8 & 11 \\
\hline 9 & 12 & 9 & 12 \\
\hline 13 & 16 & 13 & 16 \\
\hline 14 & 17 & 14 & 17 \\
\hline 15 & 18 & 15 & 18 \\
\hline 19 & 22 & 19 & 22 \\
\hline 20 & 23 & 20 & 23 \\
\hline 21 & 24 & 21 & 24 \\
\hline
\end{tabular}

Browsed Fenced Browsed Fenced diet composition was determined from the number of fragments ( $n=536$ in spring, $n=598$ in summer, $n=119$ in autumn, $n=112$ in winter) for a particular species relative to the total number of fragments.

For testing the effect of rabbit browsing on juniper survival, 24 juniper shoots of about $20 \mathrm{~cm}$ heght were planted in a grassland surrounded by old juniper patches in October, 1993. Four groups of 6 individuals were established. In each group, half of the juniper shoots were fenced and covered by plastic mesh at $5 \mathrm{~cm}$ openings against browsing while the others were left exposed. One month later, the exposure conditions were switched (Table 1). The height of each shoot was determined at the start, after ten days of exposure, and then at the end of the first and second months.

Seasonal diet differences were estimated by one-way ANOVA. Duncan's multiple range tests ( $\alpha=0.01$ ) were used to contrast main food components between seasons. Comparison of monthly browsing data on juniper shoots was performed by two-way ANOVA (treatment $\times$ time with repeated measures for the latter). Post hoc Duncan's tests were performed to compare group differences. One-sample $T$-test was used to calculate ten days effect of rabbits on heght of unfenced against fenced juniper shoots. 


\section{Results}

The ratio of the major plant groups (grasses, forbs and browses) in the rabbit diet changed significantly throughout the seasons $\left(F_{3,15}=121.4, p<0.0001\right.$ for grasses; $F_{3,15}=82.1, p<0.0001$ for forbs; and $F_{3,15}=70.1, p<0.0001$ for browses). Spring diet was dominated by grasses $(89 \%)$, while forbs were eaten mainly in summer $(42 \%)$. The importance of grass species was indicated by the high consumption of fescue Festuca vaginata in spring, brome Bromus inermis and wheat grass Agropyron repens in autumn (Table 2). On the other hand browse

Table 2. Seasonal percent composition of rabbit diets based on microhistological analyses of composite samples of fresh pellets in BJF, 1992-1993. Different letters indicate significant differences among seasons (one-way ANOVA with Duncan's multiple range tests, $\alpha=0.01$ ). $n$ - number of pellets samples.

\begin{tabular}{|c|c|c|c|c|c|}
\hline Plant groups/species & $n$ & $\begin{array}{c}\text { April } \\
42\end{array}$ & $\begin{array}{c}\text { June } \\
28\end{array}$ & $\begin{array}{c}\text { October } \\
34\end{array}$ & $\begin{array}{c}\text { December } \\
34\end{array}$ \\
\hline GRASSES & & $88 \mathrm{~A}$ & $30 \mathrm{~B}$ & $60 \mathrm{C}$ & $3 \mathrm{D}$ \\
\hline Agropyron pectinatum & & 10 & 15 & 0 & 0 \\
\hline Agropyron repens & & 0 & 0 & 27 & 0 \\
\hline Bromus inermis & & 0 & 0 & 33 & 0 \\
\hline Calamagrostis epigeios & & 0 & 6 & 0 & 0 \\
\hline Cynodon dactylon & & 4 & 0 & 0 & 0 \\
\hline Festuca spp. & & $75 \mathrm{~A}$ & $9 \mathrm{~B}$ & 0 & 0 \\
\hline Holoschoenus romanus & & 0 & 0 & 0 & 3 \\
\hline FORBS & & $6 \mathrm{~A}$ & $42 \mathrm{~B}$ & $17 \mathrm{C}$ & $15 \mathrm{AC}$ \\
\hline Ballota nigra & & 0 & 0 & 0 & 0 \\
\hline Chaenopodium spp. & & 0 & 1 & 0 & 0 \\
\hline Cynanchum vincetoxicum & & 0 & 0 & 6 & 0 \\
\hline Echinops ruthenicus & & 0 & 0 & 0 & 0 \\
\hline Melandrium album & & 0 & 3 & 0 & 0 \\
\hline Myosotis stricta & & 0 & 3 & 0 & 0 \\
\hline Potentilla arenaria & & 3 & 4 & 5 & 4 \\
\hline Thymus glabrescens & & $2 \mathrm{~B}$ & $30 \mathrm{C}$ & $6 \mathrm{BD}$ & $11 \mathrm{AD}$ \\
\hline Verbascum lychnitis & & 0 & 1 & 0 & 0 \\
\hline Unidentified & & 1 & 0 & 0 & 0 \\
\hline BROWSES & & $1 \mathrm{~B}$ & $20 \mathrm{~A}$ & $24 \mathrm{AC}$ & $60 \mathrm{D}$ \\
\hline Ligustrum vulgare & & 0 & 0 & 0 & 56 \\
\hline Prunus mahaleb & & 0 & 3 & 0 & 0 \\
\hline Robinia pseudoacacia & & 0 & 1 & 0 & 0 \\
\hline Rubus spp. & & 0 & 5 & 0 & 0 \\
\hline Salix rosmarinifolia & & $1 \mathrm{~A}$ & $11 \mathrm{BD}$ & $17 \mathrm{BC}$ & $3 \mathrm{AD}$ \\
\hline Sambucus nigra & & 0 & 0 & 7 & 0 \\
\hline PINE & & $2 \mathrm{~A}$ & $5 \mathrm{~A}$ & 0 & $19 \mathrm{~B}$ \\
\hline Juniperus communis & & $2 \mathrm{~A}$ & $4 \mathrm{~A}$ & 0 & $19 \mathrm{~B}$ \\
\hline Pinus spp. & & 0 & 1 & 0 & 0 \\
\hline SEEDS & & 3 & 3 & 0 & 3 \\
\hline
\end{tabular}




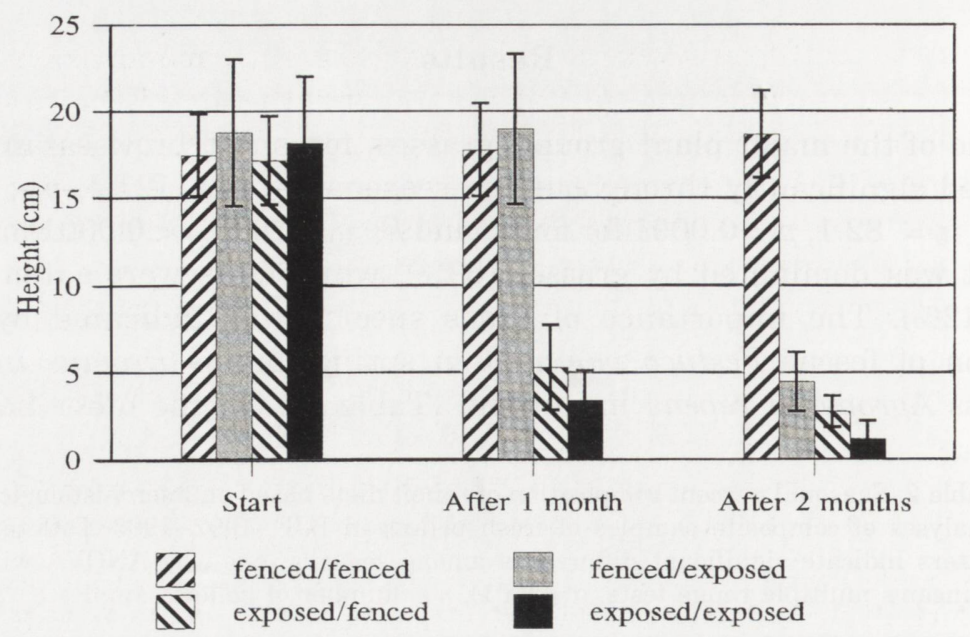

Fig. 1. Changes in the height $(\mathrm{cm})$ of juniper shoots (mean $\pm \mathrm{SE}$ ) due to rabbit grazing during the three phases of the experiment: at the start, after the first and after the second month of exposure, in BJF, 1992. $n=6$ shoots for all groups.

consumption raised from $1 \%$ in spring up to $60 \%$ in winter indicating their importance when herbaceous species are less available.

High quantities of juniper in the winter diet (19\%) corroborated visual observations of rabbits browsing on juniper. Browsing by rabbit on juniper affected the survival rate of planted juniper shoots. High significant difference $(p<0.001)$ was found even after 10 days between the mean height of fenced $(18.2 \mathrm{~cm}, \mathrm{SE}=1.05$, $n=12)$ and unfenced juniper shoots $(5.4 \mathrm{~cm}, \mathrm{SE}=0.58, n=12)$. The monthly results (Fig. 1) also showed that browsing significantly reduced the exposed shoots' height, whilst the protected individuals remained of the same size during the observation period (two-way ANOVA for treatment: $F_{3,20}=21.3, p<0.001$ ). When some protected junipers were later exposed to browsing this resulted in a decrease of their height (ANOVA for time: $F_{2,40}=190.5, p<0.001$ and treatment-time interaction: $F_{6,40}=46.5, p<0.01$ ). The continuously exposed shoots suffered the heaviest damage and remained the shortest of all plants, while fencing around browsed junipers did not result in recovery.

\section{Discussion}

Irrespective of where they live, rabbits prefer soft, low-fiber, highly nutritious annual grasses, legumes, and forbs (Myers and Bults 1977). However, rabbits may be forced to choose less nutritious but abundant food types when food shortage occurs. This general pattern of feeding strategy was also found in the BJF.

Considerable level of aromatic plants in the summer (thyme) and winter diet (juniper) contain high levels of monoterpenoid that might interfere with digestion 
(Carpenter et al. 1979), or even be toxic. For example, monoterpenoids of big sagebrush Artemisia tridentata suppressed the growth rate of the rumen micro-organisms, decreased the rate of cellulose digestion and that of gas and volatile fatty acid production by the micro-organisms in vitro (Nagy and Tengerdy 1968). However, other studies suggested that different game species such as pygmy rabbits Brachylagus idahoensis (Green and Flinders 1980), pronghorn antelope Antilocapra americana (Cluff et al. 1982) consume big sagebrush in a high amount without any apparent adverse effects. As the proportion of epidermal fragments in the pellet have been considered a reliable estimate of the diet (Johnson and Wofford 1983), the discrepancy between the adverse effects of consuming $10 \%$ thyme reported by Altbäcker et al. (1995) for domestic rabbits and the $30 \%$ of fragments of this plant in the summer fecal pellet composition of BJF wild rabbits is probably not caused by methodological constraints. Thyme might be less harmful for wild rabbits either because the wild type is better adapted to tolerate aromatic monoterpenoids, or because other plant species in the diet might reduce their toxicity in the wild. Further field and laboratory studies are needed to decide between the two alternatives.

We have recognized that rabbit pellets had a strong juniper smell after juniper consumption, and that smell was critical for transmission of juniper eating habit of rabbit does to offspring (Bilkó et al. 1994). Juniper eating had no apparent negative effects on rabbits, moreover, juniper was preferred over other plant species by weanling rabbits raised by juniper-eating mothers (Altbäcker et al. 1995). The existence of these mechanisms, together with the present results of both the diet composition and the field experiments indicate that rabbits in BJF strongly affect the survival of juniper shoots and thus constitute a significant factor of juniper dynamics.

Acknowledgements: This work was supported by the Hungarian Science Foundation (F5254/1991). We would like to thank Á. Bilkó for collecting plant samples for the Herbarium, and A. Tóbiás for contributing in the microhistological analysis. P. Kabai and an anonymous referee made valuable comments on an earlier version of this manuscript.

\section{References}

Altbäcker V., Hudson R. and Bilkó Á. 1995. Rabbit mothers' diet influence the pups' food choice. Ethology 99: 107-116.

Altbäcker V., Kertész M., Szabó J. and Förgeteg Z. 1991. The distribution of rabbit warrens in Bugac Juniper Forest (Hungary) in relation to vegetation type. Proceedings of the XXth Congress of International Union of Game Biologists, Gödölld: 1-535.

Anthony R. G. and Smith N. S. 1974. Comparison of rumen and fecal analysis to describe deer diets. The Journal of Wildlife Management 38: 535-540.

Baumgartner L. L. and Martin A. C. 1939. Plant histology as an aid in squirrel food-habits studies. The Journal of Wildlife Management 3: 266-268.

Bilkó Á., Altbäcker V. and Hudson R. 1994. Food preference transmission in the rabbit: The means of information transfer. Physiology and Behaviour 56: 907-912. 
Carpenter L. H., Wallmo O. C. and Gill R. B. 1979. Forage diversity and dietary selection by wintering mule deer. Journal of Range Management 32: 226-229.

Cluff L. K., Welch B. L., Pedersen J. C. and Brotherson J. D. 1982. Concentration of monoterpenoids in the rumen ingesta of wild mule deer. Journal of Range Management 35: 192-194.

Dusi J. L. 1949. Methods for determination of food habits by plant microtechniques and histology and their application to cottontail rabbit food habits. The Journal of Wildlife Management 13: 295-298.

Green J. S. and Flinders J. T. 1980. Habitat and dietary relationships of the pygmy rabbit. Journal of Range Management 33: 136-142.

Johnson M. K. and Wofford H. 1983. Digestion and fragmentation: influence on herbivore diet analysis. The Journal of Wildlife Management 47: 877-879.

Kalapos T. 1989. Drought adaptive plant strategies in a semiarid sandy grassland. Abstracta Botanica 13: $1-25$.

Kertész M., Szabó J. and Altbäcker V. 1993. The Bugac Rabbit Project. Part I: Description of the study site and vegetation map. Abstracta Botanica 17: 187-196.

Mátrai K. and Kabai P. 1989. Winter plant selection by red and roe deer in a forest habitat in Hungary. Acta Theriologica 15: 227-234.

Mátrai K., Koltay A. and Vizi G. 1986. Key based on leaf epidermal anatomy for food habits studies of herbivores. Acta Botanica Hungarica 32: 255-271.

Myers K. and Bults H. G. 1977. Observations on changes in the quality of food eaten by the wild rabbit. Australian Journal of Ecology 2: 215-229.

Nagy J. G. and Tengerdy R. P. 1968. Antibacterial action of essential oils of Artemisia as an ecological factor: II. Antibacterial action of the volatail oils of Artemisia tridentata (big sagebrush) on bacteria from the rumen of mule deer. Applied Microbiology 16: 441-444.

Received 23 July 1996, accepted 14 July 1997.

BIAŁOWIEŻA $\quad$ ZAKŁAD BADANIA SSAKÓW PAN POLAND

Nakład $650+50$ egz. Obj. ark. wyd. 10,59 Obj. ark. druk. 7,0

Podpisano do druku w marcu $1998 . \quad$ Druk ukończono w marcu 1998.

Skład, łamanie, diapozytywy: Zakład Badania Ssaków PAN, Białowieża

Druk: Białostockie Zakłady Graficzne w Białymstoku. 